\title{
Entre imperios: antiimperialismo e hispanoamericanismo en España contemporánea de Rubén Darío
}

\section{Among Empires: Anti-Imperialism and Hispano- Americanism in España contemporánea by Rubén Dario}

\begin{abstract}
Resumen
Este artículo examina España contemporánea. Crónicas y retratos literarios (1901) de Rubén Darío para problematizar su lugar de enunciación y perspectiva. Para ello, en la primera parte, abordamos las formas de representar el imperialismo en las crónicas darianas. En la segunda parte, proponemos que en la obra de Darío emerge una perspectiva antiimperialista e hispanoamericanista, que intenta desmarcarse del pensamiento colonial y eurocéntrico, relocalizando la cultura hispanoamericana frente a los Estados Unidos y Europa.
\end{abstract}

Palabras claves Rubén Darío, antiimperialismo, imperialismo, hispanoamericanismo, perspectiva ideológica.

\begin{abstract}
This paper examines Rubén Darío's España contemporánea. Crónicas y retratos literarios (1901) in order to problematize the author's perspective and position of enunciation. In the first part, we address the ways in which Dario's chronicles represent imperialism. In the second part, we argue that Darío displays an anti-imperialist and Hispano-Americanist perspective, distancing himself from colonial and Eurocentric thought, as well as relocating and differentially reevaluating Hispanic American culture in comparison to the United States and Europe.
\end{abstract}


CATEDRAL Tomada: Revista de crítica literaria latinoamericana / Journal of Latin American Literary Criticism Entre imperios: antiimperialismo e hispanoamericanismo en España contemporánea de Rubén Darío

Keywords Rubén Darío, Anti-Imperialism, Imperialism, Hispano-Americanism, ideological perspective

\section{El imperialismo pide sangre y oro: geopolítica y geocultura en las crónicas darianas}

"Mas si alguien dijera: «Son cosas de ideólogos. O son cosas de poetas, decir que no somos otra cosa»".

(Rubén Darío. El canto errante. 1907)

A finales del siglo XIX la expansión del imperialismo ${ }^{1}$ capitalista comienza a conectar el mundo de manera global, ya no solo gracias al militarismo y el comercio, sino también a través de la modernización de los medios de transporte y comunicación que posibilitó, entre otras cosas, el fortalecimiento de la prensa como medio de comunicación masivo (Hobsbawm 53). Las naciones hispanoamericanas se integran más activamente en los circuitos comerciales y culturales que Europa y los Estados Unidos difundían e imponían como modelos hegemónicos para el resto del planeta.

En la esfera letrada se produce paralelamente una modernización en la forma de comprender la literatura, que se manifiesta en la profesionalización del escritor hispanoamericano y la conformación de industrias culturales (Montaldo

${ }^{1}$ Entendemos el imperialismo como un fenómeno que durante el último tercio del siglo XIX se encuentra asociado al desarrollo del capitalismo eurooccidental a escala planetaria. En términos amplios, nos parece aquí operativa la distinción entre imperio e imperialismo propuesta por Michael Doyle, quien señala que: "imperio es una relación, formal o informal, en la cual un Estado controla la soberanía política efectiva de otra sociedad política. Puede conseguirse por la fuerza, por la colaboración política, económica, social o por dependencia cultural. Imperialismo es el proceso de establecimiento y mantención de un imperio" [Empires are relationships of political control imposed by some political societies over the effective sovereignty of other political societies. They include more than just formally annexed territories, but they encompass less than the sum of all forms of international inequality. Imperialism is the process of establishing and maintaining an empire. La traducción nos pertenece] (19). Bajo esta perspectiva, los Estados Unidos también se convirtieron en una nación con vocación imperialista en América Latina durante los siglos XIX y XX, aunque fue un imperio informal, es decir, un caso de imperialismo sin un imperio colonial mayor como fueron los Estados imperiales europeos decimonónicos (Osterhammel 22). 
81). Estas circunstancias generaron, de acuerdo a Susana Zanetti, una "condición imprescindible para que fuera posible un movimiento mancomunado en concepciones estéticas e ideológicas, para que surgiera el intercambio y la discusión entre pares, medianamente generalizada y con cierta simultaneidad" ("Modernidad" 500). Julio Ramos ha advertido asimismo que en el período finisecular aparecen "nuestros primeros intelectuales modernos, no porque fueran los primeros en trabajar con «ideas», sino porque ciertas prácticas intelectuales, sobre todo ligadas a la literatura, comenzaban a constituirse fuera de la política y frecuentemente opuestas al Estado, que había ya racionalizado y automatizado su territorio socio-discursivo" (99). Por su parte, Ángel Rama ha considerado que esta autonomía relativa se relaciona con la instauración de la economía capitalista en América Latina, que introdujo: "la división del trabajo, principio que acarrea la forzosa especialización y simultáneamente la pérdida de la visión totalizadora, unificadora e interpretativa, de la actividad humana" (Rubén Dario 44).

En este escenario geocultural y geopolítico, situamos a Rubén Darío (18671916), intelectual ${ }^{2}$ que se destacó principalmente en la práctica y renovación de la poesía hispanoamericana, aunque también escribió novelas, cuentos y cientos de crónicas periodísticas. En la presente investigación examinaremos España contemporánea. Crónicas y retratos literarios $(1901)^{3}$, que reúne 42 crónicas, escritas por Darío en su calidad de corresponsal de La Nación de Buenos Aires,

${ }^{2}$ Utilizamos este concepto en el marco de la historia intelectual y de los intelectuales de Latinoamérica para visibilizar la función de mediador y traductor cultural que Darío cumple al articular lo literario con lo político en su trabajo escritural y en su contribución en la conformación del cenáculo modernista, tanto en América como en Europa. En tal perspectiva, nos parece pertinente destacar que, como afirma Carlos Altamirano, los intelectuales: "son personas, por lo general conectados entre sí en instituciones, círculos, revistas, movimientos, que tienen su arena el campo de la cultura. Como otras élites culturales, su ocupación distintiva es producir y transmitir mensajes relativos a lo verdadero (si se prefiere: a lo que ellos creen verdadero), se trate de los valores centrales de la sociedad o del significado de su historia, de la legitimidad o la injusticia del orden político, del mundo natural o de la realidad trascendente, del sentido o del absurdo de la existencia [...] la acción de los intelectuales se asocia con lo que Régis Debray llama grafoesfera -es decir, con el dominio que tiene su principio en la existencia de la imprenta, los libros, la prensa- $[\ldots]$ Los intelectuales se dirigen unos a otros, a veces en la forma de debate, pero el destinatario no es siempre endógeno: también suelen buscar que sus enunciados resuenen más allá del ámbito de la vida intelectual, en la arena política" (14-15).

${ }^{3}$ En nuestro trabajo utilizamos la prolija edición crítica realizada por Noel Rivas Bravo, en 2013. 
CATEDRAL Tomada: Revista de crítica literaria latinoamericana / Journal of Latin American Literary Criticism Entre imperios: antiimperialismo e hispanoamericanismo en España contemporánea de Rubén Darío

entre el 3 de diciembre de 1898 y el 7 de abril de 1900. El periódico bonaerense le encargó la escritura de estos textos con el objeto de "ofrecer a sus lectores un testimonio de primera mano de la situación española después de la derrota frente a los Estados Unidos" (Vilanova 9). Sin embargo, su misión en España no es solo periodística, sino que responde además a "los intereses informativos e ideológicos de La Nación y por lo tanto para el grupo social que dicho diario representa" (Rama, "Sueños" 40).

Hemos elegido España contemporánea dentro de la voluminosa y sobrecogedora producción periodística de Darío, porque estimamos que sus crónicas escenifican una serie de problemáticas asociadas con la emergencia de una subjetividad moderna y un pensamiento crítico supranacionales, que después de la derrota española del 98 comienza a replantear la cuestión de la identidad cultural hispanoamericana (Bonfiglio 74-75) ${ }^{4}$. Para Graciela Montaldo, en este período los intelectuales cierran sus filas "rescatando más que las tradiciones criollas, una nueva alianza con el hispanismo (es decir, con sus élites), pero no sólo como alternativa frente a la penetración norteamericana sino también -y especialmentecomo regulación interna de los nuevos públicos latinoamericanos" (85). Claudio Maíz observa también que frente al surgimiento del imperialismo estadounidense "los intelectuales hispanoamericanos reconsideran el problema a la luz de un principio racial: latinos frente a sajones" (122). En tal dirección, consideramos que Darío, a partir de su experiencia en la España del "desastre", enfatiza su actitud ideológico-política al revalorizar la unidad cultural hispanoamericana frente a la amenaza que representa el mundo anglosajón norteamericano, tal como lo hacen otros escritores de entresiglo como José Martí (1853-1895), José María Vargas Vila (1860-1933), César Zumeta (1860-1955), José Enrique Rodó (1871-1917), Rufino Blanco Fombona (1874-1944), Manuel Ugarte (1875-1951), entre los más

${ }^{4}$ La Guerra hispano-cubano-norteamericana de 1898 en la que España fue derrotada en tan solo tres meses por los Estados Unidos provocó la pérdida de sus colonias de Cuba, Puerto Rico y Filipinas. Esta guerra, como parte importante de la historiografía lo ha destacado, marcó el ascenso imperial de los norteamericanos en el sistema mundial, porque rebasó sus fronteras continentales al comenzar a ejercer su poder político, militar y económico también en Asia (Bender 231-232). 
destacados. Es, además, para Rama, un período crucial en la producción dariana, pues marca una línea divisoria en su obra posterior, en tanto se sitúa tácticamente desde una perspectiva hispanoamericana ("Sueños" 35) 5 . Debemos precisar que si bien en estas crónicas su preocupación se orienta más hacia el ámbito estéticocultural, no por ello deja de examinar los aspectos políticos, sociales, económicos e históricos que observa en su visita a la Península Ibérica. Noel Rivas Bravo ha señalado al respecto que en este libro Darío es un poeta pensador o pensador poeta que analiza la realidad del disminuido imperio y "cree en el futuro de España. Un futuro que debe cimentarse en dos direcciones, una realista y práctica y otra romántica e idealista" (17).

Es necesario consignar en este lugar que Darío utiliza la crónica periodística como un espacio de reflexión crítico y artístico que es equivalente al trabajo del escritor, tal como él lo precisa en "El periodista y su mérito literario", cuando señala: "El periodista que escribe con amor lo que escribe, no es sino un escritor como otro cualquiera" (220). Y en otro momento el mismo autor considera que "el periodismo constituye una gimnasia de estilo" ("Letras" 113). Susana Rotker ha indicado que en un principio para los escritores modernistas el periodismo "donde comunicación y creación, información, presiones externas y arte parecían reñidas [...] terminaron encontrando en las crónicas su espacio de resolución" (116). La crónica hispanoamericana se transformó entonces en una plataforma escritural en la cual a su vez "se puso a prueba la modernidad de la escritura modernista, y se llevó a la literatura hasta el límite de sus capacidades para inscribir el momento presente" (González 82). Y lo moderno en el caso de Darío también se conecta con su capacidad de percibir y analizar los acontecimientos geopolíticos y sociales del cambio de siglo: la caída del alicaído imperio colonial español y el nacimiento del imperialismo moderno estadounidense (Bender 219).

${ }^{5}$ En el presente artículo, preferimos hablar de hispanoamericanismo que de latinoamericanismo en el caso de Darío, ya que, como ha puesto de relieve Susana Zanetti, sus "vínculos con Brasil son aún escasos y no se presiente una pertenencia común con el Caribe no hispanohablante" ("Modernidad" 492). Para una mirada general sobre esta temática en la obra literaria dariana, véase José Alberto Barisone. "La perspectiva americanista de Rubén Darío". 
Pues bien, teniendo presente este ámbito teórico-genérico, nuestro propósito principal es analizar e identificar la perspectiva ideológica que construye Darío en España..., centrándonos principalmente en los ejes político, social, cultural y literario que se registran en esta obra. Proponemos que en sus crónicas emerge una perspectiva antiimperialista e hispanoamericanista que es representativa de un sector de los intelectuales latinoamericanos del periodo y dialoga con una parte importante de su propia producción periodística; que en este caso se expresa, por un lado, en una crítica al imperialismo estadounidense y, por otro, en la recuperación de la herencia cultural hispana dentro de un proyecto hispanoamericanista trasatlántico que es consecuencia, en parte, de la amenaza imperialista anglosajona. En los trabajos de este libro observaremos que existe un esfuerzo por desmarcarse del pensamiento colonial y eurocéntrico en tanto busca relocalizar la cultura hispanoamericana en el marco del mundo occidental, con el objeto de integrar la producción artístico-intelectual del subcontinente en los procesos modernizadores europeos, aunque resguardando una cierta autonomía cultural. De todas formas, reconocemos que Darío mantiene un lugar de enunciación eurocentrado e inestable ${ }^{6}$, cuyo paradigma cultural será París (como lo fue para muchos modernistas) ${ }^{7}$, reproduciendo ciertos estereotipos y esquemas de

${ }^{6}$ Para la distinción entre lugar de enunciación y perspectiva seguimos a Walter Mignolo, quien propone el concepto de pensamiento fronterizo, situado entre fronteras geopolíticas y culturales (28). A su vez, distingue dos tipos de pensamiento fronterizo, uno fuerte y uno débil, este último "surge de los desheredados, del dolor y de la furia de la fractura de sus historias, de sus memorias, de sus subjetividades, de su biografía, como queda claro, por ejemplo, en Waman Poma de Ayala o en Frantz Fanon" (28). Por otra parte, el pensamiento fronterizo fuerte "no es producto del dolor y la furia de los desheredados mismos, sino de quienes no siendo desheredados toman la perspectiva de éstos [...] Lo que importa es que, en la geopolítica del conocimiento, la misma perspectiva puede asumirse desde distintos lugares de enunciación (epistémicos)" (28). Más allá de la categoría de pensamiento fronterizo, de la que tomamos distancia, nos interesa la idea de que muchas veces el lugar de enunciación no coincide con la perspectiva que se presenta en un autor determinado, situación que intentaremos mostrar en la obra del escritor nicaragüense. En lo referente a la inestabilidad del lugar de enunciación de Darío, nos basamos en los planteamientos de Silvia Tieffemberg, quien considera que es una característica propia de la enunciación mestiza en América Latina, tal como sería el caso de nuestro poeta (273).

${ }^{7}$ En este punto estamos de acuerdo con Mariano Siskind, quien ha advertido que la preferencia de Darío por Francia no se relacionaría solo con un afrancesamiento personal y obtuso, sino que su "francofilia universalista debe ser leída como un efecto teórico-cultural del Modernismo global. Desde la independencia de las colonias españolas hasta el fin de la Segunda Guerra Mundial el privilegio ontológico del significante francés se consolidó en función de una doble operación 
pensamientos cuya matriz es posible rastrear en el discurso colonial hispano y occidental. Se intentará demostrar esta situación al abordar la norma civilizatoria que Darío establece en su discurso, que se vincula con la búsqueda de una renovación y proyección cosmopolita de la cultura de Hispanoamérica frente al intervencionismo político estadounidense y la influencia cultural europea en la región, una problemática que también será una preocupación transversal a su obra poética $^{8}$.

Antes de comenzar con el examen de la obra es necesario situarla dentro de la producción dariana que reflexiona sobre los diferentes imperios occidentales de su época. Partiremos de varios trabajos que han abordado el pensamiento antiimperialista de Darío acerca de los Estados Unidos ${ }^{9}$. Se considera que sus textos clásicos sobre el tema son: en crónica "El triunfo de Calibán” (1898), en prosa “Edgar Allan Poe” (1896) y “D. Q” (1899), mientras que en poesía su conocida oda

trasatlántica. Por un lado, Francia -como formación cultural que hablaba mejor que ninguna otra el lenguaje de la modernidad- representaba su particularidad como si fuese idéntica a la universalidad moderna [...] Por otro lado, los intelectuales latinoamericanos afirmaban y reproducían este axioma cultural sin cuestionar sus premisas esencialistas" (255). Es importante señalar aquí que ya en el mismo periodo en que Darío escribió España...no manifestaba una admiración irreflexiva por París, pues era capaz de observar sus claroscuros. En "Reflexiones de año nuevo parisiense" (La Nación, 5 de febrero de 1901) anota: "Lo que en París se alza al comenzar el siglo XX es el aparato de la decadencia [...] Hay muchos franceses ilustres, muchos franceses nobles, muchos franceses honrados que meditan silenciosos, luchan con bravura o lamentan la catástrofe de la moral. Pero las ideas de honor, las viejas ideas de generosidad, de grandeza, de virtud han pasado" (116-117).

${ }^{8}$ Si bien excede los límites de nuestro trabajo que se enfoca en las crónicas darianas, es relevante advertir que en su poesía realizó denodados esfuerzos por poner en perspectiva el canon literario europeo y estadounidense con respecto a la poesía hispanoamericana de su tiempo y a su propia poética. En sus conocidas y estudiadas "Palabras liminares", de Prosas profanas y otros poemas (1896), expresa sobre este asunto: "(Si hay poesía en nuestra América, ella está en las cosas viejas: en Palenke y Utatlán, en el indio legendario, y en el inca sensual y fino, y en el gran Moctezuma de la silla de oro. Lo demás es tuyo, demócrata Walt Whitman.) [...] El abuelo español de barba blanca me señala una serie de retratos ilustres: «Este, me dice, es el gran don Miguel de Cervantes Saavedra, genio y manco; éste es Lope de Vega, éste Garcilaso, éste Quintana». Yo le pregunto por el noble Gracián, por Teresa la Santa, por el bravo Góngora y el más fuerte de todos, don Francisco de Quevedo y Villegas. Después exclamo: ¡Shakespeare! ¡Dante! ¡Hugo...! (Y en mi interior: / Verlaine...!). Luego al despedirme - «Abuelo, preciso es decíroslo: mi esposa es de mi tierra; mi querida, de París» (9-10).

${ }^{9}$ Sobre la evolución de la obra de Darío en relación con los Estados Unidos, recomendamos el clásico artículo de David Allen. "Rubén Darío frente a la creciente influencia de los Estados Unidos". Para un balance de los autores que han problematizado la representación del país del norte en Darío y un estudio más actualizado sobre esta temática, véase de Alberto Acereda. "Las otras miradas de Rubén Darío a Estados Unidos". 
“A Roosevelt" (1904) $)^{10}$, contenida en su libro Cantos de vida y esperanza (1905).

Este libro de Darío se considera asimismo como una obra definitoria de su hispanismo (Martínez, "Introducción” 58), donde formula una constante reflexión crítica sobre la amenaza imperial de los Estados Unidos que conjuga lo estético y lo político en su propuesta poética, tal como escribe en la sentencia final de su prefacio: "Si en estos cantos hay política, es porque aparece universal. Y si encontráis versos a un presidente, es porque es un clamor continental. Mañana podremos ser yanquis (y es lo más probable); de todas maneras mi protesta queda escrita sobre las alas de los inmaculados cisnes, tan ilustres como Júpiter" (334) ${ }^{11}$.

Ahora bien, la obra antiimperialista de Darío también ha sido valorada por la crítica como una posición circunstancial frente a los Estados Unidos, desarrollada fundamentalmente tras 1898, como sus poemas de Cantos..., pero que tuvo un carácter oscilante y contradictorio (Acereda, "Silencios" 76). Se cita, en este

${ }^{10}$ Tal vez el mayor esfuerzo por el estudio y recopilación de las obras antiimperialistas y políticas de Darío ha sido realizado por Jorge Eduardo Arellano en diversos trabajos. Son emblemáticos su ensayo para Casa de las Américas "Rubén Darío antimperialista" (1982) y el libro antológico, Tantos vigores dispersos (1984). Este último, no obstante, descontextualiza a Darío al transformarlo anacrónicamente en un pensador revolucionario. En la presentación de Tantos... redactada por el Consejo Nacional de la Cultura de Nicaragua, por ejemplo, se declara: "Los sesentitrés [sic] fragmentos de Rubén Darío que Jorge Eduardo Arellano selecciona, titula y anota en esta entrega, se inscriben en la línea de recuperación impulsada por nuestro proceso [...] De ahí que revelen un Darío sensible a la injusticia, capaz de advertir y denunciar la explotación y los vicios del sistema capitalista. Un Darío abierto a los precursores del pensamiento social moderno. Un hombre de ideas, lector de Marx y Engels, abierto a los problemas de la sociedad industrial de Europa, indignado por los atropellos del imperialismo. En fin, un Darío revolucionario que anuncia el futuro socialista de la humanidad" (7). Estos trabajos de Arellano tampoco problematizan las ambigüedades ideológicas del poeta. Corresponden más bien a una reivindicación y apropiación política de un Darío antiimperialista que, de acuerdo a Diana Moro, ya había aparecido en la década de los 60 en Cuba y que continuaron los sandinistas con el objeto de arrebatarle el poeta a la burguesía, haciéndolo "parte de la iconografía revolucionaria, junto a la figura señera de César Augusto Sandino" (41).

${ }^{11}$ En este mismo poemario también es destacable su soneto, "Los cisnes", dedicado a Juan Ramón Jiménez, en el que Darío, al igual que en el citado "A Roosevelt", versifica la política expansionista de los Estados Unidos y la caída del imperio hispano mediante una serie de metáforas zoológicas: "La América española como la España entera/ Fija está en el Oriente de su fatal destino;/ Yo interrogo a la Esfinge que el porvenir espera/ Con la interrogación de tu cuello divino/ ¿Seremos entregados a los bárbaros fieros?/ ¿Tantos millones de hombres hablaremos en inglés?/ ¿Ya no hay nobles hidalgos ni bravos caballeros?/ ¿Callaremos ahora para llorar después?/ He lanzado mi grito, Cisnes, entre vosotros/ Que habéis sido los fieles en la desilusión,/ Mientras siento una fuga de americanos potros/ Y el estertor postrero de un caduco león” (380). 
sentido, con frecuencia el poema "Salutación al águila" (1906) $)^{12}$. Sin embargo, en las últimas décadas, gracias a las investigaciones sobre su labor periodística y con la reedición de una importante cantidad de crónicas que solo habían aparecido en la prensa de la época ${ }^{13}$, nos ha permitido indagar con mayor acuciosidad su perspectiva antiimperialista, que fue, como pretendemos demostrar, persistente (aunque con tensiones) y que no se limitó a los Estados Unidos.

Al explorar por orden cronológico sus trabajos, por ejemplo, en La Nación de Buenos Aires y El Heraldo de Costa Rica, observamos que la visión crítica de Darío sobre el imperialismo estadounidense fue una constante en su producción intelectual. Tempranamente, antes del 98, encontramos crónicas de El Heraldo, donde se manifiesta a favor de la defensa del subcontinente frente a las diversas intervenciones de Estados Unidos. "Bronce al soldado Juan" (1891) ${ }^{14}$ y "Por el lado del Norte" $(1892)^{15}$ son una muestra de ello. Sobre todo en la primera crónica en que rescata y valora la figura de Juan Santamaría, héroe costarricense que luchó contra la invasión de William Walker, en 1856 (207). Por otra parte, en La Nación identificamos una serie de crónicas que no solo impugnan el accionar expansionista estadounidense, sino también el del imperio español, como se puede observar en "La insurrección en Cuba" (1895) ${ }^{16}$, en la que toma una posición en pro de los revolucionarios cubanos José Martí, Antonio Maceo y Máximo Gómez (13-16). Tras la Guerra Hispano-Norteamericana, su postura se concentrará en el análisis del imperialismo estadounidense en el subcontinente, como en "El triunfo de

\footnotetext{
12 Texto que generó más de un descontento entre sus contemporáneos. En este marco, una de las polémicas más recordadas fue la que entabló con su amigo Rufino Blanco Fombona. Ante estas críticas y consciente de la controversia, Darío escribirá una carta, en 1907, al escritor venezolano: "Saludar nosotros al Águila, ¡sobre todo cuando hacemos cosas diplomáticas!... no tiene nada de particular. Lo cortés no quita lo Cóndor..." (Cit., en Acereda, "La Hispanidad" 106).

${ }^{13}$ Muchas de sus crónicas fueron recopiladas en vida por Darío en: España contemporánea (1901), Peregrinaciones (1901), La caravana pasa (1902), Tierras solares (1904), Parisiana (1907), El viaje a Nicaragua e intermezzo tropical (1909) y Todo al vuelo (1912). Pero debido al carácter misceláneo de estas obras, se pierde de vista la perseverancia de sus preocupaciones geopolíticas.

${ }^{14} 15$ de septiembre de 1891 .

1515 de marzo de 1892.

162 de marzo de 1895.
} 
CATEDRAL Tomada: Revista de crítica literaria latinoamericana / Journal of Latin American Literary Criticism Entre imperios: antiimperialismo e hispanoamericanismo en España contemporánea de Rubén Darío

Calibán" (1898) ${ }^{17}$ y "El crepúsculo de España"18, junto con una amplia lista de trabajos para La Nación que se intensificará, según Rocío Oviedo, después de la injerencia de Estados Unidos en Panamá, en 1903, con el Tratado Hay-Bunau Varilla $(221)^{19}$. Aunque, como ha apuntado Alberto Acereda, Darío rechazó la política imperialista estadounidense sin dejar de admirar su pragmatismo y constancia: "Elogio a sus grandes poetas, a sus hombres de ciencia, y, en general, a los hombres de buena fe, y a su libertad, su autodeterminación, su independencia" (“La hispanidad" 107).

Sumado a los textos revisados ya sobre España y los Estados Unidos, Darío escribió un conjunto de crónicas que tratan sobre los problemas del imperialismo y el colonialismo europeos y los conflictos inter-imperiales de la época que son dignas de mencionar. Un texto muy interesante es "Andrianamanitra mby an-trano" $(1901)^{20}$, que describe la llegada de la reina de Madagascar a París, introduciendo varias recriminaciones al imperialismo francés y al racismo que lo sostiene. Darío escribe al respecto:

[...] la reina no dispone sino de lo que el gobierno de Francia le quiere dar, en pupilaje [...] Y para colmo de desventura de la infeliz, cuando ha adoptado las modas europeas, comprado bicicleta, aprendido un poco de piano, y venido a París con licencia, se la recibe como a una macaca, se la

\footnotetext{
${ }^{17}$ En El Tiempo de Buenos Aires, 20 de mayo de 1898 y unos meses después en El Cojo Ilustrado de Caracas, 1 de octubre de 1898.

${ }^{18}$ En El Mercurio de América, Buenos Aires, noviembre de 1898.

${ }^{19}$ Algunas de las crónicas de La Nación, posteriores al 98, en que Darío criticará a los Estados Unidos son: "La invasión de los bárbaros del Norte" (30 de diciembre de 1901), "La cuestión de los canales" (9 de marzo de 1902), "Los Estados Unidos y América Latina" (6 de abril de 1902), "La invasión anglosajona. Centro América yanqui" (23 de abril de 1902), "La fuerza yanqui" (18 de mayo de 1902), "El arte de ser presidente de la república. Roosevelt" (13 de noviembre de 1904), "El viaje a Nicaragua/(Para La Nación) IV" (1 de noviembre de 1908), "La antidiplomacia: una nota de Mr. Knox" (1 de abril de 1910), "Roosevelt en París" (22 de junio de 1910), "La política americana: Zelaya responde a Taft" (25 de febrero de 1911), "El canal de Panamá" (21 de mayo de 1912), "El fin de Nicaragua" (28 de septiembre de 1912) y dos años antes de su muerte, escribió "Asuntos americanos/la intención yanqui" (6 de julio de 1914).

207 de julio de 1901, incorporado por el autor en La caravana pasa, 1902.
} 
llama negra y fea a cada paso, y poco falta para que se la proponga una contrata en un circo. (91-93)

El autor también desmantela en esta crónica las estrategias retóricas del imperialismo al percibir los conflictos entre estos: "El inglés encuentra muy legítima su acción en el Transvaal y condena la del francés en Madagascar; el francés considera que tenía derecho a tomarse Madagascar; pero que el inglés, al conquistar Transvaal, se ha portado como un salteador" (91).

También Darío trata el tema colonial e imperial en “Gibraltar” (1904) $)^{21}$, "Viejo y nuevo Japón" (1904) 22 y "La cuestión de marruecos. El sultán íntimo" $(1906)^{23}$. En relación con el imperialismo británico ${ }^{24}$ redacta dos crónicas para el diario de los Mitre: “John Bull for ever" $(1895)^{25}$ y "En Londres" $(1901)^{26}$.

Lo interesante en la mayoría de estos textos es que Darío, parafraseando a Walter Benjamin, fluctúa entre la estetización de la política y la politización de la estética para representar el imperialismo moderno y los conflictos sociopolíticos que advierte ${ }^{27}$. Una crónica poco estudiada y que exhibe con elocuencia esta

${ }^{21} 18$ de abril de 1904, incorporado por el autor ese mismo año en Tierras solares.

222 de octubre de 1904.

${ }^{23} 17$ de febrero de 1906.

${ }^{24}$ El escritor argentino Eduardo Muslip ha afirmado que Darío no sería un crítico del imperialismo europeo, pues dice, al examinar La vida de Rubén Darío escrita por él mismo (1912), que su "mirada afectuosa hacia Francia y hacia Inglaterra excluye toda referencia al rol político imperial que ejercen [...] no tiene ningún problema en rescatar para esta autobiografía un poema llamado «God save the Queen», una apología de Inglaterra en todos los aspectos, cultural, moral, político y el específicamente imperial" (45). Discrepamos con la posición de Muslip por dos razones; primero, porque su juicio se deriva del análisis de una sola fuente, ignorando las crónicas darianas que hemos venido estudiando, y, segundo, ya que el poema citado no es primordialmente una loa a la política imperialista británica, sino más bien es un poema panegírico a la reina y a la historia de la nación, tal como Darío lo aclara en su libro citado: "Otro de mis amigos, que ha sido siempre fraternal conmigo, era Charles E. F. Vale, un inglés criollo incomparable. Una noche, con motivo del aniversario de la reina Victoria, le dicté en el restaurant de «Las 14 provincias», un pequeño poema en prosa dedicado a su soberana, que él escribió a falta de papel en unos cuantos sobres y que no ha aparecido en ninguno de mis libros" (168).

2523 de marzo de 1895.

${ }^{26} 15$ de septiembre de 1901, incorporado por el autor en La caravana pasa, en 1902.

${ }^{27}$ Conocida es la sentencia de Benjamin expuesta en su ensayo, "La obra de arte en la época de su reproductibilidad técnica" (1936), donde escribe: "La humanidad, que antiguamente, en Homero era un objeto de contemplación para los dioses olímpicos, se ha convertido en objeto de contemplación de sí misma. Su autoalienación ha alcanzado tal grado que le permite vivenciar su propia aniquilación como un goce estético de primer orden. Así es la estetización de la política 
CATEDRAL Tomada: Revista de crítica literaria latinoamericana / Journal of Latin American Literary Criticism Entre imperios: antiimperialismo e hispanoamericanismo en España contemporánea de Rubén Darío

situación es "Cake-walk" $(1903)^{28}$, donde describe y analiza el baile afroestadounidense que había llegado a París como una novedosa expresión de la cultura yanqui (349). Pero no solo se dedica a valorar artísticamente la danza como una moderna escenificación corporal, sino que desde el inicio mezcla con maestría el juicio estético y el político: "Como el negro de la anécdota, el yanqui continúa, continúa en su expansión universal, y una de sus manifestaciones es hoy la danza" (349). Más adelante añade, con mordacidad, que el presidente Roosevelt instrumentaliza políticamente el cake-walk:

[...] se complace en regocijar a sus jubilosos compatriotas de color, que no caben en sí de crespa vanidad; mientras un autorizado periodista declara en tal diario neoyorquino que lo mejor sería mandar al diablo la doctrina Monroe y repartirse con algunas potencias europeas los suculentos pedazos de la América Latina; mientras los varios reyes de Chicago, Manhattan, Frisco y demás lugares se divierten con el juego del trust, el cake-walk conmueve al mundo. (349-350)

Y al finalizar el artículo sentencia: "Para ser tan joven, no lo hace tan mal el siglo XX... He ahí la obra del imperialismo, he ahí la obra de la omnipotencia de los millones del Norte" (352). Un elemento destacable en esta crónica es que Darío, por un lado, muestra que el imperio estadounidense también se constituye como un espectáculo estético-cultural y, por otro, utiliza el término imperialismo para referirse a los Estados Unidos, demostrando su actualizado conocimiento del vocabulario geopolítico de aquel entonces, pues el concepto de imperialismo era

que el fascismo practica. El comunismo le responde con la politización del arte" (128). En Darío, en cambio, la estetización de la política y la politización del arte se vinculan con la plasticidad estilística y estética que le otorga la crónica como soporte textual heterogéneo de cruces discursivos, donde puede conservar una relativa autonomía con respecto al campo político y partidario.

2819 de marzo de 1903. 
poco manejado en política exterior y menos aún en el concierto latinoamericano ${ }^{29}$. Será solo después del libro de John A. Hobson Estudio del imperialismo (1902) y del ensayo de Lenin Imperialismo, fase superior del capitalismo (1916) que el término adquirirá una preeminencia política e interpretativa de envergadura dentro del léxico de las relaciones internaciones (Hobsbawm 60) ${ }^{30}$. A su vez, no es la primera ocasión en la que Darío ha empleado dicho término en sus escritos, sino que ya lo ha usado en la casi desconocida crónica "El cuerpo diplomático hispanoamericano"31, en la que previene: "La expansión futura del imperialismo anglosajón no es un sueño; y la probabilidad de lucha de razas tampoco" (252). Un año más tarde en la crónica "En Londres" analizará críticamente la política exterior del imperio británico, mediante el manejo de metáforas que equiparan el imperialismo a la rapacidad animal: "Esta gente va, va ¿A dónde va? Adelante, más adelante lo dicen en sus divisas, en sus proloquios, cortos, porque no son verbosos como nosotros los latinos, raza de rectores [...] País de rapiña, se dice; tanto peor

${ }^{29}$ Hay que tener en cuenta que el empleo del lenguaje político de Rubén Darío se puede deber a que desde los inicios de su carrera literaria ocupó variados cargos vinculados a la diplomacia, que también fue un área de la que escribió varias crónicas. Cabe recordar que la diplomacia fue una esfera de acción donde los intelectuales latinoamericanos de fin de siglo podían combatir la estrechez económica y ampliar sus horizontes intelectuales (Myers 41). Darío, por ejemplo, en 1892 fue jefe de la comisión para representar a Nicaragua en las Celebraciones del Cuarto Centenario del Descubrimiento de América en España. Al año siguiente fue nombrado Cónsul de Nicaragua y Colombia en Argentina. Entre 1903-1907, ejerció como Cónsul de Nicaragua en París. En 1907, fue nombrado Ministro Residente en Madrid, representando al gobierno de Nicaragua. Su último cargo diplomático fue, entre 1912 y 1914, cuando fue designado por Paraguay para ser su Cónsul en París. Paralelamente a estos nombramientos, Darío participó, en 1905, en la comisión nicaragüense para resolver los conflictos limítrofes con Hondura. En 1906, asistió como representante de Nicaragua en la Conferencia Interamericana de Río de Janeiro, en la que compuso su polémico poema "Salutación al águila". Podemos reconocer en los diferentes papeles diplomáticos que Darío desempeñó, simultáneamente a su profesión de cronista y escritor, una importante función intelectual que, como hemos señalado, articula el campo literario con el político sobre todo en sus crónicas, que es un espacio textual donde los discursos literarios, culturales y políticos se encuentran imbricados. Para una descripción general de los puestos diplomáticos ocupados por Darío, recomendamos revisar de Norman Caldera. Rubén Darió diplomático (2006).

${ }^{30}$ Eric Hobsbawm ha precisado que: "el término imperialismo se incorporó al vocabulario político y periodístico durante la década de 1890 en el curso de los debates que se desarrollaron sobre la conquista colonial. Además, fue entonces cuando adquirió, en cuanto concepto, la dimensión económica que no ha perdido desde entonces" (60).

3129 de abril de 1900. Este texto pertenece al mismo periodo de las crónicas redactadas para España contemporánea, no obstante, Darío no la incluye en este libro ni en ningún otro. Recientemente ha sido rescatada por Noel Rivas Bravo en la edición de España ... que utilizamos aquí. 
CATEDRAL Tomada: Revista de crítica literaria latinoamericana / Journal of Latin American Literary Criticism Entre imperios: antiimperialismo e hispanoamericanismo en España contemporánea de Rubén Darío

para los que no pueden resistirle y caigan bajo su zarpa [...] Esa gente va, va" (28) y declara con ímpetu y preocupación: “El imperialismo pide sangre y oro" $(37)^{32}$.

Es útil subrayar que nos parece significativo cómo el intelectual centroamericano está reaccionando textualmente frente al imperialismo de entresiglo, porque lo está evaluando e interpretando no solo en su condición de fenómeno político, económico y militar, sino también como una práctica representacional y un control discursivo relacionados con la cultura eurooccidental, que ha constituido su propia retórica imperial o modo de escribir sobre los pueblos no occidentales para sostener su dominio (Spurr 20). Para esta tarea, Darío va construyendo un discurso de resistencia y oposición, con vacilaciones, que trata de situar diferencialmente la cultura hispanoamericana en el orden geocultural y geopolítico que el imperialismo occidental está elaborando.

Por último, debemos realizar dos observaciones en relación con la perspectiva de Darío sobre los imperios modernos. Por una parte, frente a los críticos que identifican la presencia de cierta ambigüedad o niegan que haya rechazado el imperialismo (Muslip 45), necesitamos consignar que cuando emplea el término siempre lo presenta de forma negativa. Además, que la admiración de Darío por los Estados Unidos, Francia, Inglaterra o España, reconocible en varias de sus obras, corresponde a un rescate social y cultural, en clave cosmopolita, que no necesariamente coincide con una valoración de la política exterior imperialista que estas naciones efectuaban. Por otro lado, Alberto Acereda ha señalado que considerar a Darío como antiimperialista es una deformación propia del "odio a EEUU del dogmatismo marxista" (“El acecho” 266) que "perpetuó la presentación de un Darío muy distinto a su verdadera ideología. Así se imprimieron y comentaron hasta la saciedad -en uso y consumo que sigue hasta nuestros días-

32 También manejará, hasta donde pudimos investigar, la palabra imperialismo en varias crónicas más: "La invasión anglosajona. Centro América yanquil" (1902), "Los Estados Unidos y la América Latina" (1902), "El arte de ser presidente de la república. Roosevelt" (1904), "La antidiplomacia: una nota de Mr. Knox" (1910), "La política americana: Zelaya responde a Taft" (1911), "El fin de Nicaragua" (1912), “Asuntos americanos/la intención yanqui” (1914). Y en trabajos no periodísticos como: "Dilucidaciones" (prólogo de El Canto Errante, 1907) y en su obra de carácter autobiográfico, Historia de mis libros (1916). 
ciertos textos darianos referidos a los Estados Unidos" ("El acecho" 266). No obstante, Acereda olvida o desconoce que el antiimperialismo no solamente fue y ha sido un pensamiento crítico del marxismo o las izquierdas, sino que también fue sostenida por pensadores tan disímiles como John A. Hobson y Mark Twain ${ }^{33}$. En consecuencia, que Darío haya enunciado posiciones antiimperialistas no lo transforma tampoco en un liberal o en marxista, pues el antiimperialismo no corresponde a una ideología partidaria determinada, es más bien una actitud política y un discurso de resistencia cultural que puede conectarse con diferentes cuerpos doctrinarios y que se activa en determinadas coyunturas signadas por la injerencia imperialista (Kozel, Grossi y Moroni 12-14). Por lo tanto, si bien reconocemos las vacilaciones ideológicas de Darío, consideramos que en su caso y en la historia intelectual latinoamericana "es conveniente tener en mente un concepto flexible de antiimperialismo, atento a las diferencias en las interpretaciones individuales y a los cambios operados en el tiempo, en las propias ideas y en las posiciones políticas e ideológicas de los distintos autores" (Pita y Marichal 12).

\section{Don Quijote no puede ni debe morir: hispanoamericanismo y retórica del desastre}

Las crónicas de Darío sobre España son fundamentales para comprender el papel ideológico que estos textos tuvieron en el marco del resurgimiento del hispanismo y del proceso de reconciliación político-cultural con la denominada Madre Patria (Zea 19), que durante gran parte del siglo XIX había sido marginada

${ }^{33}$ Hobson, economista británico liberal y pro capitalista, es un importante crítico del imperialismo de su época, pues señala: "no sólo impide el avance hacia el internacionalismo al fomentar la enemistad de los imperios rivales, sino que, con su ataque contra las libertades y contra la propia existencia de las razas más débiles o inferiores, provoca en éstas un exceso correlativo de autoconciencia nacional" (25). Es menester indicar asimismo que una de las primeras Ligas Antiimperialistas no surgió al alero del pensamiento marxista, sino en los Estados Unidos y encabezada por Mark Twain en 1898. Dicha Liga, fue "fundada en Boston con la aspiración básica de combatir y denunciar las implicaciones de la Guerra Cubano-Hispano-Norteamericana de ese año" (Quesada Monge 165). 
de los proyectos nacionales y culturales de los intelectuales liberales, pues lo hispano representaba el mundo colonial, el oscurantismo y la tiranía política. Ya en 1892 Darío había comprendido la importancia de reestablecer los lazos culturales entre España y sus ex colonias, cuando fue enviado por el gobierno nicaragüense a Madrid con la finalidad de que participase en las conmemoraciones y festejos del IV Centenario del Descubrimiento de América (Schmigalle 153).

Algunos meses antes de su segundo arribo a España, Darío había escrito "El triunfo de Calibán", profusamente citado, donde expone su defensa de la herencia latina frente al expansionismo anglosajón: "No, no puedo, no quiero estar de parte de esos búfalos de dientes de plata. Son enemigos míos, son los aborrecedores de la sangre latina, son los Bárbaros. Así se estremece hoy todo noble corazón, así protesta todo digno hombre que algo conserve de la leche de la Loba" (184). Con esta retórica que estetiza y metaforiza a los Estados Unidos, Darío subvierte el binomio del colonialismo de civilización/barbarie, en tanto en este lugar es identificado el país del norte con el Calibán de la tradición shakesperiana ${ }^{34}$ y la barbarie (categoría imputada generalmente a los pueblos no occidentales durante la Modernidad $)^{35}$.

Poco tiempo después de la publicación de esta crónica, Darío escribe "En el mar", con que abre España contemporánea, estableciendo una reconciliación en su discurso con la ex Metrópoli: "De nuevo en marcha, y hacia el país maternal que el alma americana-americanoespañola- ha de saludar siempre con respeto, ha de

${ }^{34}$ Carlos Jáuregui realiza una interesante interpretación sobre la apropiación modernista de las figuras de Ariel y Calibán, al destacar que: "Las metáforas shakesperianas y panlatinistas del latinoamericanismo del fin de siglo ponen en evidencia, además, el eurocentrismo de la intelligentsia latinoamericana, y su marginalidad o localización periférica (neo) colonial. Al nombrar su causa de identidad como la de la raza latina, acudían a una idea racista, de factura francesa y paradójicamente diseñada en el proceso de constitución del botín americano que se disputaban potencias como Inglaterra, Francia y los Estados Unidos. Los alegatos contra Calibán (de Groussac, Darío y Rodó) están enunciados desde la pérdida de autoridad del letrado característica del Modernismo y desde un espacio cultural cuyos referentes han sido descentrados por la emergente supremacía económica, militar y tecnológica de los Estados Unidos" (342-343).

${ }^{35}$ Durante esta época de su vida, Darío también escribe una serie de poemas que exhiben su hispanismo y su solidaridad con la España herida: "Cyrano en España", "Al rey Óscar", "Retratos y "Trébol" (todos publicados en diversos medios de prensa, en 1899), que unos años después serán reunidos en Cantos de vida y esperanza. 
querer con cariño hondo. Porque si ya no es la antigua poderosa, la dominadora imperial, amarla el doble; y si está herida, tender a ella mucho más" (37). En esta cita reconocemos un giro en la perspectiva ideológica que desde comienzos del siglo XIX habían mantenido letrados como Andrés Bello (1781-1865), Simón Bolívar (1783-1830) y Francisco Bilbao (1823-1865), quienes buscaban justamente romper con la herencia colonial hispana. Darío, en cambio, introduce un neologismo (americanoespañol) para expresar su doble conciencia y su filiación espiritual con la cultura peninsular, aunque es notable que anteponga lo americano a lo español ${ }^{36}$, porque manifiesta su voluntad de enfatizar su posición desde el Nuevo Continente frente a la España "herida", realizando "la fusión de lo viejo y lo nuevo" (Gutiérrez Girardot 153). Se debe relevar que aunque en este discurso se elabora la recuperación de un proyecto sociocultural común con "el país maternal”, relación filial propia del discurso hispanista (Núñez 143), se establece también un significativo silencio sobre las culturas subalternizadas (pueblos originarios y afrodescendientes principalmente) que conforman el continente americano ${ }^{37}$.

${ }^{36}$ Es interesante destacar aquí que Darío subvierte el orden de la identidad cultural que el jesuita Juan Pablo Viscardo y Guzmán (1748-1798) había elaborado en su famosa "Carta dirigida a los españoles americanos" (1792), donde la identificación con lo español se anteponía a lo americano dentro de su proyecto político emancipador. Darío llegando casi al final de su vida, en Historia de mis libros, vuelve a reforzar su perspectiva geocultural americano-española, cuando retrospectivamente declara sobre la elaboración y propuesta poética de Cantos de vida y esperanza: "Mi optimismo se sobrepuso. Español de América y americano de España, canté, eligiendo como instrumento al hexámetro griego y latino, mi confianza y mi fe en el renacimiento de la vieja Hispania, en el propio solar y del otro lado del Océano, en el coro de naciones que hacen contrapeso en la balanza sentimental a la fuerte y osada raza del norte" (205-206).

${ }^{37}$ Más adelante examinaremos brevemente la visión estereotipada que Darío posee sobre el mundo indígena americano en la obra que estamos analizando. Mientras que en relación con los afrodescendientes americanos en España ... no emite juicios sustanciales. Sin embargo, Darío en otra fundamental crónica, "La raza de Cham" (1907), expresa un discurso racista propio de un importante sector letrado de la época, mostrando su desprecio por los negros: "Así, pues, de Haití llegan á Francia malas nuevas. La macacada está furiosa; los pocos blancos que hay en la isla ven con temor la agitación de los naturales. Saben que una insurrección de color es terrible para los europeos. En el negro, danzante, tristón, jovial, pintoresco, carnavalesco, surge, con el fuego de la cólera y el movimiento de la revuelta en antepasado antropopiteco, el caníbal de África, la fiera obscura de las selvas calientes" (261) y después agrega: "Su imaginación [...] les hace concebir una fantástica vida de jolgorios y alegrías, antes tan solamente permitidos á los aborrecidos blancos... La vanidad, que les es característica -no hay vanidad como la del piel obscura- les induce á imitar los gestos y maneras del caballero blanco, del antiguo patrón. El ministrel se pavonea. Su teoría, su sueño, su meta, es la igualdad. Pero que no tenga la más simple representación, la autoridad más pequeña, el honor más mínimo, porque entonces se convierte en el peor tirano" (267). Para un sugestivo análisis y una mirada más amplia acerca del problema de las 
En la crónica inaugural de su estadía española, "En Barcelona”, Darío presenta a la ciudad como un modelo industrial, artístico e intelectual que encarna de mejor manera el pensamiento moderno, ya que es superior al resto de las ciudades hispanas, incluyendo a la capital imperial, Madrid (38). Es una ciudad señala Darío "riente, alegre, bulliciosa, moderna, quizá un tanto afrancesada y por lo tanto llena de elegancia" (36). Lo que identificamos aquí es su inclinación por el modelo de ciudad moderna que encarna Barcelona (cuyo paradigma es Francia) en tanto lo estético, lo industrial, lo intelectual y lo social se conjugan allí. Sin embargo, detrás de esa idealización Darío observa críticamente los nuevos sujetos y clases sociales (proletariado urbano) que genera el sistema industrial. Con el fin de representar esta realidad social, narra con un dejo de ironía una anécdota que presenció en un café:

[...] cerca de mí, en una de las mesitas, dos caballeros, probablemente hombres de negocios o industriales, elegantemente vestidos, conversaban con gran interés y atención, cuando llegó un trabajador con su traje típico $\mathrm{y}$ ese aire de grandeza que marca en los obreros de aquí un sello inconfundible; miró a un lado y otro, y como no hubiese mesas desocupadas cerca de allí, tomó una silla, se sentó a la misma mesa en que conversaban los caballeros y pidió como lo hubiera hecho el mismo Vifredo el Velloso, su taza. Le fue servida, tomándola, pagó y fuese como había entrado, sin que los dos señores suspendiesen su conversación, ni se asombrasen de lo que en cualquier otra parte sería acción osada e impertinente. Por la Rambla va ese mismo obrero, y su paso y su gesto implican una posesión inaudita del más estupendo de los orgullos; el orgullo de una democracia llevada hasta el olvido de la superioridad, a punto de que se diría que todos estos hombres de las fábricas tienen una corona de conde en el cerebro. (46-47)

representaciones de las diferencias raciales y culturales en las obras de los modernistas hispanoamericanos, recomendamos revisar de Iris Zavala. "The Dialogical Cultural Signs". 
En esta extensa cita, distinguimos varios elementos que son fundamentales con respecto a nuestro objeto de estudio, pues se escenifica con mayor fuerza la perspectiva ideológica y el lugar de enunciación del discurso de Darío. Más allá de la referencialidad de esta anécdota, identificamos un posicionamiento de clase ante lo que parece perturbar el orden social desde el cual evalúa el mundo, pues, aunque lo hace indirectamente, estima que el comportamiento del obrero fue una "acción osada e impertinente". En primer lugar, Darío establece implícitamente una contraposición de clase entre los "hombres de negocios o industriales, elegantemente vestidos" y el obrero "con su traje típico y ese aire de grandeza". En esta contraposición, si bien reconocemos, como ha advertido Leonel Delgado, que "hay algo de estetización en esta visión política de la modernidad” (21), pensamos que, además, expresa una aversión frente a un sector social que se presenta como fuera del lugar que le pertenece, sin respetar a esos "caballeros" y su "conversación" al "sentarse en la misma mesa". Asimismo, el obrero nunca es calificado ni como "señor" ni como "caballero", solamente se alude a su orgullo, e incluso, Darío lo compara irónicamente con Wifredo el Velloso, considerado padre de la independencia catalana. Con la misma ironía, termina diciendo que "todos estos hombres de las fábricas tienen una corona de conde en el cerebro”. En segundo lugar, el cronista revela una distancia crítica ante las nuevas relaciones político-sociales que se darían en Barcelona, puesto que el obrero personifica "el orgullo de una democracia llevada hasta el olvido de la superioridad", lo que podría interpretarse como un rasgo un tanto conservador y contrario a una democracia que ha olvidado "la superioridad", vale decir, a un sistema que no respeta las individualidades y diferencias de clases dentro de la división social del trabajo naturalizada por el sistema capitalista ${ }^{38}$. Desde este punto de vista, consideramos que esta fe en la modernización es ambigua dentro de su perspectiva, en tanto no

\footnotetext{
${ }^{38}$ Pablo Kraudy señala que Darío no era admirador de la democracia, sino que reproduce "la práctica latinoamericana del siglo XIX, en donde la democracia no es equivalente a voluntad numérica. La base de este criterio era la creencia de que el pueblo aún no estaba capacitado para ejercer los roles que aquella demandaba" (76-77).
} 
CATEDRal Tomada: Revista de crítica literaria latinoamericana / Journal of Latin American Literary Criticism Entre imperios: antiimperialismo e hispanoamericanismo en España contemporánea de Rubén Darío

hay una valoración positiva de las nuevas corrientes ideológicas que surgen con la Modernidad y los procesos de modernización industrial ${ }^{39}$. En este contexto, Darío se expresa también con cierta desconfianza sobre los movimientos socialistas y anarquistas catalanes:

La ciudad se agita. Por todos lugares la palpitación de un pulso, el signo de una animación. Las fábricas a las horas del reposo, vacían sus obreros y obreras. El obrero sabe leer, discute; habla de la R.S., o sea, si gustáis, Revolución Social; otro mira más rojo, y parte derecho a la anarquía. No muestran temor ni empacho en cantar canciones anárquicas en sus reuniones, y sus oradores no tienen que envidiar nada a sus congéneres de París o de Italia. Ya recordaréis que se ha llegado aquí a la acción, y memorias sonoras y sangrientas hay de terribles atentados [...] Hace poco, en una fiesta industrial, en momentos en que llegaban amargas noticias de la guerra, ciertos trabajadores arrancaron de su asta una bandera de España y la sustituyeron por una bandera roja. (49)

A diferencia de la anécdota del obrero, aquí su perspectiva no es tan marcadamente adversa respecto a estos grupos, ya que se limita primordialmente a informar sobre las acciones llevadas a cabo por ellos. Sin embargo, existe una especie de exotización del obrero, pues se destaca que "sabe leer", "discute", no muestra "temor", características que al parecer son inusuales para un sujeto de esta clase en la mirada dariana.

En la suma total de estas citas, es posible reconocer que Darío se ancla en el ideario del letrado decimonónico, buscando resguardarse de las ideologías

\footnotetext{
${ }^{39}$ Julio Ramos ha sugerido que para los principales modernistas latinoamericanos, como Darío, las masas obreras representaban una barbarie interior de la civilización que era necesaria reformar, por esta razón: "los ensayistas refuncionalizan las retóricas literarias, normativas, contra el «caos» social y la masificación, reclamando para la disciplina de las humanidades un lugar rector en la administración y control de un mundo donde proliferaba una nueva forma de la «barbarie»: la «masa» obrera" (273).
} 
igualitaristas que anteponen sus intereses de clase por encima de proyectos nacionales ${ }^{40}$. Así, en este discurso está tratando de mantener un cierto orden social liberal en el marco de la exaltación del individualismo que respete las jerarquías sociales y en oposición a las muchedumbres ${ }^{41}$. Por último, en la crónica antes mencionada, "En el mar", advertimos también un rechazo hacia los pasajeros de la tercera clase que van en el barco, presentándolos como un "montón de hombres que se aglomera como en un horrible panal" (39) y los describe de un modo despectivo: "Hoy penetré en el ambiente infecto de ese rebaño humano que exigiría la fumigación” (39). Es necesario precisar, además, que la aversión enunciada por Darío en torno a los nuevos sectores y clases sociales populares que la modernización capitalista estaba generando en la América Latina y Europa del cambio de siglo, se convirtió en una de las características centrales de un grupo significativo de intelectuales latinoamericanos modernistas, quienes poseían un alto concepto de Europa, cuya "identificación clasista con la alta cultura y su occidentalismo, los ponía del lado de la «civilización» y del apolíneo Ariel; los hacía rechazar cualquier protagonismo identitario proveniente de la efervescencia popular" (Jáuregui 344).

Ahora bien, uno de los aspectos relevantes de la obra analizada es la perspectiva que construye sobre el pasado y presente imperial hispano. En esta serie

${ }^{40}$ Un dato biográfico relevante es que Darío conoció de cerca y se interesó por parte del ideario socialista y anarquista en Buenos Aires. Estableció relaciones de amistad con Roberto Payró, Ricardo Jaimes Freyre, José Ingenieros, Alberto Ghiraldo, Manuel Ugarte, entre otros (Zanetti, "El modernismo" 529), reputados pensadores y fundadores del pensamiento argentino de izquierdas. Además, escribió varias crónicas sobre socialismo y anarquismo, por ejemplo, "Dinamita" donde repudia un atentado anarquista (La Tribuna, Buenos Aires, 27 de noviembre de 1893). Incluso también participó en algunas revistas anarquistas, aunque sin compartir su ideario (Acereda, "Silencios" 155). En "Un paseo con Núñez de Arce", de España ..., expone el obstáculo que los grupos ácratas, socialistas e incluso los nihilistas representan para la recuperación del proyecto nacional hispano: "El fracaso impera en todo. La sociedad, después de tantos siglos, no ha logrado aún resolver el problema de su misma organización. Véanse las rojas flores que brotan en el terreno: se llaman socialismo, anarquismo, nihilismo. ¡La nacionalidad española! un sueño" (277).

${ }^{41}$ Darío en la crónica "Un «meeting» político" confiesa: "La muchedumbre me es poco grata con su rudeza e higiene. Me agrada tan solamente de lejos, como un mar; o mejor, en las comparsas teatrales, florecida de trajes pintorescos, así sea coronada del frigio pimiento morrón" (269). De este modo, su apreciación de las muchedumbres es valorada en su contemplación estética y desde un distanciamiento enunciativo. 
de crónicas la imagen de España entregada por Darío se elabora a través de una retórica del desastre que le permite caracterizar y evaluar al imperio en sus diferentes niveles: social, político, artístico-cultural y económico. Por ejemplo, en "Madrid", percibe que existe "en la atmósfera una exhalación de organismo descompuesto" (56), y que también reconoce en las emblemáticas figuras del hispanismo y del conservadurismo político (Núñez 149). Darío enumera el estado actual de las cimas intelectuales que había conocido en 1892: "Cánovas muerto; Ruiz Zorrilla muerto; Castelar desilusionado y enfermo; Valera ciego; Campoamor mudo; Menéndez Pelayo... No está por cierto España para literaturas, amputada, doliente, vencida" (56).

Esta representación del desastre y fracaso imperial, Darío la visualiza también en el retorno de los soldados derrotados y cadavéricos: "van llegando a los puertos de la patria los infelices soldados de Cuba y Filipinas [...] otros no alcanzan la tierra y son echados al mar, y los que llegan andan a semejanza de sombras; parecen, por cara y cuerpo, cadáveres" (57). Una imagen opuesta a lo que divisa en la sociedad, que se encuentra alejada de los avatares del poder y de la guerra: “Acaba de suceder el más espantoso de los desastres; pocos días han pasado desde que en París se firmó el tratado más humillante en que la mandíbula del yanquee quedó por el momento satisfecha después del bocado estupendo: pues aquí podría decirse que la caída no tuviera resonancia" (56). Como hemos analizado, la perspectiva que se va esbozando en algunas crónicas de este libro devela la posición de Darío frente al conflicto cultural y político que visualiza entre el orbe hispanoamericano y el sajón representado en esa "mandíbula" calibánica del imperialismo estadounidense. Por otra parte, en esta crónica no solo realiza un recuento crítico de la situación social y cultural de España tras la derrota, sino que responsabiliza a los líderes políticos de causar la debacle:

Ellos son los que han encanijado al León simbólico de antes; ellos los que han influido en el estado de indigencia moral en que el espíritu público se encuentra; los que han preparado, por desidia o malicia, el terreno falso de 
los negocios coloniales, por lo cual no podía venir en el momento de la rapiña anglosajona sino la más inequívoca y formidable débâcle. (58)

Nótese que el rescate del león como símbolo imperial muestra una cierta nostalgia frente a, en sus palabras, ese "imperio hecho polvo" (57). Darío, en la crónica "Cyrano en casa de Lope", con un gesto de apreciable ambigüedad desea un resurgimiento del león imperial, que está encarnado en diversas figuras de la cultura y tradición hispanas, emplazando a recuperar el espíritu del Quijote que ha sido desplazado por el "espíritu sanchesco" que "impide toda ascensión" (90):

Don Quijote no debe ni puede morir; en sus avatares cambia de aspecto, pero es el que trae la sal de la gloria, el oro del ideal, el alma del mundo. Un tiempo se llamó el Cid, y aun muerto ganó batallas. Otro, Cristóbal Colón, y su Dulcinea fue la América. Cuando esto se purifique - ¿será por el hierro y el fuego?- quizá reaparezca, en un futuro renacimiento, con nuevas armas, con ideales nuevos, y entonces los hombres volverán a oír, Dios lo quiera, entre las columnas de Hércules, rugir al mar, con sangre renovada y pura, el viejo y simbólico león de los iberos. (90-91)

Con este discurso de corte espiritualista y con estetización modernista, escenifica su admiración por el pasado imperial y colonial hispano y su deseo de renovación de España, aunque sublimando los conflictos político-ideológicos que cada una de las figuras mencionadas representan. Además, es interesante la feminización del continente americano al convertirlo en Dulcinea, mujer idealizada de Don Quijote, pues Darío inscribe en forma de romance la compleja relación colonial de España con el Nuevo Mundo. Desde este punto de vista, podemos señalar que la perspectiva antiimperialista del cronista es ambigua y no necesariamente contra el colonialismo o anticolonialista, puesto que, para validar su proyecto americano-español, elude en cierto modo los problemas políticos, raciales y culturales, que conformaron la historia colonial hispanoamericana. Si 
bien Darío lamenta la emergencia del nuevo imperio estadounidense, "no deja de hacer lo mismo por el fin del imperio anterior" (Jáuregui 345). Así, reproduce en parte el discurso colonial e imperial hispano, actualizado en el siglo XIX por intelectuales como Marcelino Menéndez Pelayo (1856-1912) ${ }^{42}$, que veían en la colonización y conquista de América un proceso civilizador beneficioso para ambos lados del Atlántico (Díaz Quiñones 81-82).

No obstante lo anterior, en "La «España negra»" Darío expresa una posición crítica al reinstalar algunos de los tópicos de la leyenda negra, mostrando el lado oscuro del colonialismo que en la antes examinada omitía:

Los conquistadores y los frailes en América no hicieron sino obrar instintivamente, con el impulso de la onda nativa: los indios despedazados por los perros, los engaños y las violencias, las muertes de Guatimozin y Atahualpa, la esclavitud, el quemadero y la obra de la espada y el arcabuz, eran lógicos, y tan solamente un corazón excepcional, un espíritu extranjero entre los suyos, como Las Casas, pudo asombrarse de esa manifestación de la España Negra. (125)

Aquí, la perspectiva de Darío se sitúa en favor de los indios, pero en una operación retórica que parece sin tanta fuerza y algo estereotipada, porque, por una parte, reproduce el discurso tradicional de la leyenda negra, cuya matriz proviene del pensamiento de Bartolomé de Las Casas, y, por otra, el escritor toma una distancia enunciativa al no reconocerse ni cultural ni étnicamente en ese mundo indígena americano, que es presentado como víctima pasiva y silente frente al aparato imperial hispano. No obstante, se define como un católico que no busca atacar a España, sino que persigue la superación del fanatismo que ha perjudicado a esta sociedad. El cronista anota: "Mal podría yo, católico, atacar lo que venero;

\footnotetext{
42 Vale la pena recordar que Darío conoce bien la obra de este pensador hispano y mantuvo relaciones de amistad, a quien estimaba como un modelo de humanista e intelectual. Prueba de ello es la crónica que le dedica en España ...: "Homenaje a Menéndez Pelayo".
} 
mas no puedo desconocer que el catolicismo español de hoy dista en su pequeñez largamente aun del terrible y dominante catolicismo de los autos de fe" (130). Y más adelante escribe: "España ha de ser siempre católica o no será” (131). Delgado ha apuntado que en esta crónica Darío recomienda "una salida espiritualista para España, que equilibra el catolicismo tradicional y la modernidad" (27). Aunque también nos habla del lugar de enunciación rubendariano, en tanto se sitúa desde una práctica religiosa europea impuesta en América de la que se siente heredero y defensor ${ }^{43}$.

Ahora bien, Darío en España contemporánea nunca expresa una posición clara en torno a la esfera política hispana, en la que se enfrentaban fuertemente monárquicos y republicanos, sobre todo después de la derrota con los Estados Unidos. Sin embargo, como ha estudiado Antonio De la Torre, Darío se inclina por escribir y reunirse con "los paladines de la democracia española, los pensadores y hombres de acción que durante las últimas décadas habían sido el sostén y alma del movimiento republicano" (269). Así, ocurre, por ejemplo, con las crónicas, estudios e innumerables citas que les dedica a las obras y personalidades de Emilio Castelar (1832-1899), Benito Pérez Galdós (1843-1920) y Miguel de Unamuno (1864$1936)^{44}$. O su texto "Un meeting político" en el que relata su asistencia a una asamblea de los republicanos madrileños, aunque sin emitir opiniones políticas muy comprometedoras.

Donde tal vez encontramos una definición más evidente con respecto a la política y monarquía española es en su texto "La joven aristocracia", en el que declara: "En todas partes, y por su propia culpa, la nobleza ha perdido terreno" (369). Y después complementa esta idea, indicando: "En nuestras democracias, la presencia de un noble siempre es decorativa en la vida social. Huelen esos caballeros, mal educados, ignorantes, obtusos, pero casi siempre ¡visten tan bien!

\footnotetext{
${ }^{43}$ Para el estudio y profundización de la relación entre el Modernismo de Darío y sus concepciones religiosas, recomendamos el artículo de José María Martínez. "Modernismo literario y modernismo religioso: encuentros y desencuentros en Rubén Darío”.

${ }^{44}$ En esta dirección, véase: "La legación Argentina. En casa de Castelar", "La Pardo Bazán en París. Un artículo de Unamuno" y "Una novela de Galdós".
} 
A América suelen llegar gentleman y escrocs" (369). De esta forma, muestra un desdén por la nobleza como clase social que es inútil en los sistemas democráticos americanos $\mathrm{y}$, de paso, su pensamiento antimonárquico, aunque se presente de manera indirecta a través de su reprobación del mundo noble y aristócrata. Para Darío, en España la nobleza ha sido uno de los factores de la decadencia, porque no es productiva dentro del capitalismo que lleva adelante los procesos de modernización durante la época: "De antiguo he sabido la poca afición al trabajo de la nobleza española [...] Familias llenas de oro y acostumbradas al regalo, mal podían pensar en otra cosa que en los privilegios de su grandeza" (371). En resumen, para Darío la nobleza manifiesta un retroceso en los tiempos modernos para la sociedad española, y con un discurso propio del ideario liberal republicano remata: "No, no puede aguardar nada España de su aristocracia. La salvación, si viene, vendrá del pueblo guiado por su instinto propio, de la parte laboriosa que representa las energías que quedan del espíritu español, libre de políticos logreros y de pastores lobos" (376). Recordemos nuevamente que la mención al pueblo debe estar tamizada por un ideario republicano elitista y a una retórica modernista, más que a una vocación democrática como la entendemos hoy.

Por otra parte, en la crónica "La novela americana en España", Darío busca revertir el desconocimiento que exhiben los escritores hispanos acerca de la producción novelística y cultural hispanoamericana, quienes consideran que "todo lo nuestro es irremediablemente tropical, o cubano" (346). Pero tal vez su objetivo primordial en este trabajo consiste en concretar la unión del campo cultural hispanoamericano a ambos lados del Atlántico, que para los modernistas, en general, "implicaba el fortalecimiento de un sistema literario común en el mercado internacionalizado de las letras" (Bonfiglio 71). Un elemento destacable de Darío también es que concibe el campo literario desde una perspectiva hispanoamericanista, donde lo espiritual y racial se pone en relación con la herencia colonial hispana, aunque reconociendo la especificidad social y cultural americana: 
Los glóbulos de sangre que llevamos, la lengua, los vínculos que nos unen a los españoles no pueden realizar la fusión. Somos otros. Aun en lo intelectual, aun en la especialidad de la literatura, el sablazo de San Martín desencuadernó un poco el diccionario, rompió un poco la gramática. Esto no quita que tenemos la unidad en el espíritu de la raza. (347)

Julio Ortega ha visto en ese "Somos otros" la "autodefinición dariana del modernismo hispanoamericano; pero también como su teoría cultural implícita, no por subjetiva menos rigurosa que cualquier otra" (144). Una teoría cultural que, en este caso, se presenta como la configuración de un proyecto novelístico que en Hispanoamérica era una tarea que todavía no se había desarrollado completamente. Por otro lado, Darío en este texto también contribuye con la estabilización de un canon hispanoamericano de escritores y obras, destacando: Amalia (1851-1855), de José Mármol, María (1867), de Jorge Isaacs, y La Bolsa (1898), de Julián Martel. Cabe señalar, sin embargo, que ninguna de ellas corresponde, según él, a la verdadera novela americana. Para Darío, el único que ha logrado escribirla es el argentino Eduardo Gutiérrez (1851-1889) y, aunque no nombra su novela, se colige que alude a Juan Moreira (1878-1888). De ella comenta:

Ese bárbaro folletín espeluznante, esa confusión de la leyenda y de la historia nacional en escritura desenfadada y a la criolla, forman, en lo copioso de la obra, la señal de una época en nuestras letras. Esa literatura gaucha es lo único que hasta hoy puede atraer la curiosidad de Europa: ella es un producto natural, autóctono, en su salvaje fiereza y poeta va el alma de la tierra. (347-348)

Se ha advertido que "Ese bárbaro folletín espeluznante" es "casi un oxímoron y quiere decir: narrativa latinoamericana, discurso cuya fuerza «nueva» se apodera del género popular, de la prensa, para inscribir su propio relato sobre el palimpsesto de los géneros, sobre la textualidad de la novela, un instrumento 
privilegiado de la modernidad" (Ortega 145). Darío, entonces, rescata una novelística que sea capaz de ficcionalizar la realidad americana en clave nacional, a través del binomio civilización/barbarie de Sarmiento, representando lo exótico y regional como elementos fundacionales de las identidades nacionales criollas. En este sentido, busca diferenciar la literatura americana de la española y europea dentro de su proyecto modernista. Una literatura que será legitimada bajo el criterio estético legatario del Romanticismo europeo que privilegia la originalidad y la novedad. De este modo, concordamos con Leonel Delgado, quien ha señalado que la barbarie americana se puede modernizar en la perspectiva ideológica dariana:

Narrándola de forma otra y estética [...] Sin embargo, el «bárbaro folletín» identifica en tanto circula desde el exotismo hasta la tradición, y, de vuelta, a la barbarie. De manera que la modernidad es introducida como factor que impulsa la circulación de los géneros originales y excéntricos ante diferentes autoridades que los sancionan o no (aunque el criterio europeo sea la medida). En otras palabras, el modernismo también se puede leer en la barbarie. (31)

Desde este punto de vista, Darío está conciliando la producción literaria local y autónoma con su ideal cosmopolita y su proyecto modernizador de las letras hispanoamericanas. Tal vez por esta razón, en la crónica analizada termina elogiando la novela naturalista, Todo un pueblo (1899), del venezolano Miguel Eduardo Pardo (1868-1905), residente en París, al describir e interpretar el resumen de su argumento:

La tragedia que anima la narración tiene por escenario un pedazo de esas Américas cálidas, con sus ciudades semicivilizadas y sus campañas pletóricas de vida, sembradas de bosques en que impera la más bravía naturaleza y en donde se refugia el alma del indio, el alma libre del indio de antaño, afligida de la opresión y decaimiento de los restos de tribus del 
indio de ahora. Y es la preponderancia de los descendientes de los conquistadores, de los mestizos enriquecidos; el producto de la raza de los aventureros y hombres de presa que llegaron de España y la raza indígena, que dio por resultado una sociedad sin génesis bien esclarecido, que tuvo como las sociedades europeas su aristocracia, su clase media y su plebe. (351)

En este fragmento se textualizan una serie de tópicos provenientes del discurso colonial que han sido re-actualizados por los discursos nacionalistas liberales, interpretando la novela como una "tragedia" racial, mediante el uso de una red conceptual que enfatiza lo exótico y salvaje en contraposición con lo europeo. Así, Darío problematiza la identidad cultural hispanoamericana en tanto un origen signado por el mestizaje y la indefinición. Pese a ello, el rescate de la novela pasa por la reproducción de la mirada europea con respecto al continente americano, pues no logra rebasar los límites categoriales de civilización/barbarie. Si bien este binomio fue impuesto en el campo intelectual hispanoamericano gracias principalmente a Sarmiento, no por ello se debe desconocer que, como ha indicado Roberto Fernández Retamar, corresponde a una dicotomía, arcaica y etnocéntrica, arquetípica del discurso colonial e imperial "que desde finales del siglo XVIII propaga la Europa capitalista en desarrollo" (33) para justificar su invasión y dominación de los pueblos no occidentales.

Por último, existe un notable silencio de Darío que es necesario destacar en España...: su posición política frente a la independencia cubana. El conflicto no es tratado explícitamente en ninguno de los trabajos de esta obra. Un tema no menor pensando en el contexto en que escribió sus crónicas, al considerar además, como indicamos antes, que había respaldado la causa cubana, y que conocía de cerca los planteamientos que José Martí había pronunciado al respecto ${ }^{45}$. Solo advertimos un

${ }^{45}$ Cabe recordar que Darío escribió una laudatoria semblanza de José Martí en su libro Los raros (1896), en la que valora la maestría poética del intelectual antillano, que había fallecido recientemente. Además, el nicaragüense conoció personalmente a Martí en Nueva York, en 1893, mientras el cubano se encontraba en el exilio a causa de sus actividades independentistas. De este 
apoyo indirecto a la lucha de Cuba en "Cyrano en casa de Lope", la misma crónica en que recuerda con nostalgia el imperialismo hispano. Sin embargo, en un pequeño acápite que pone en voz del periodista y político español, Julio Burell, Darío señala: "hoy el romanticismo que muere en Europa revive en América y en Oceanía. Cyrano de Bergerac - una fe, un ideal, una bandera, un desprecio de la vida- se llama Menelik en Abysinia, Samory en el Senegal, Maceo en Cuba y en Filipinas Aguinaldo" (86). Lo interesante en este lugar es que Darío a través de una crítica de arte (de una representación teatral) encuentra la oportunidad para introducir de contrabando sus posiciones políticas, donde valora la emergencia de los movimientos de liberación nacional y anticolonialistas de las periferias imperiales, aunque sea de forma cauta y sucinta. Así, observamos que en una misma crónica Darío textualiza actitudes opuestas, rasgo que pone de manifiesto, una vez más, su lugar inestable de enunciación.

Es posible interpretar tal vez que parte de la respuesta al casi nulo tratamiento a la causa cubana, la podemos encontrar en "El triunfo de Calibán", donde señala: "Y yo que he sido partidario de Cuba libre, siquier fuese por acompañar en su sueño a tanto soñador y en su heroísmo a tanto mártir, soy amigo de España en el instante en que la miro agredida por un enemigo brutal, que lleva como enseña la violencia, la fuerza y la injusticia" (455). De este modo, Darío antepone el proyecto de unidad hispanoamericana por sobre los conflictos políticos e identitarios nacionales, pues los Estados Unidos son percibidos como una amenaza mayor y directa en el subcontinente mientras que España es un imperio en retirada ${ }^{46}$.

encuentro Darío escribirá: "Martí me esperaba esa noche en Harinand Hall, en donde tenía que pronunciar un discurso ante una asamblea de cubanos [...] Yo admiraba altamente el vigor general de aquel escritor único, a quien había conocido por aquellas formidables y líricas correspondencias que enviaba a diarios hispanoamericanos. Martí tenía esa noche que defenderse. Había sido acusado, no tengo presente ya si de negligencia, o de precipitación, en no sé cuál movimiento de invasión a Cuba. Es el caso, que el núcleo de la colonia le era en aquellos momentos contrario [...] pronunció en aquella ocasión uno de los más hermosos discursos de su vida, el éxito fue completo y aquel auditorio antes hostil, le aclamó vibrante y prolongadamente" (La vida 142-143).

${ }^{46}$ José María Martínez considera que hay dos razones sobre el relegamiento de la lucha política cubana entre los modernistas: "quizá la principal y más obvia, sería el hecho de que el destino de Cuba, para Darío y para el resto de los escritores no cubanos, era una cuestión sin implicaciones 
Darío en otra interesante crónica, "El modernismo", escribe:

Gran orgullo tengo aquí de poder mostrar libros como los de Lugones o Jaimes Freire entre los poetas, entre los prosistas poemas, como esa vasta, rara y complicada trilogía de Sicardi [...] Y otras demostraciones de nuestra actividad mental -no la profusa y rapsódica, la de cantidad, sino la de calidad, limitada, muy limitada, pero que bien se presenta y triunfa ante el criterio de Europa- estudios de ciencias políticas, sociales. Siento igual orgullo. (328)

En este discurso se exhibe su perspectiva hispanoamericanista, al evaluar con "orgullo" la "calidad" de "nuestra actividad mental" y el desarrollo de las obras intelectuales. Darío se presenta "como mediador y organizador de las nuevas corrientes estéticas frente a los resabios de realismo, naturalismo y academicismo" (Colombi 126). Ejerce entonces la función de difusor de la cultura hispanoamericana en el Viejo Continente, realizando un desplazamiento en las relaciones de producción de saberes o, en sus palabras, "actividad mental": desde el ex mundo colonial busca colonizar figuradamente a España mediante los conocimientos y creaciones literarias generados por los letrados criollos al difundirlos entre los intelectuales peninsulares. En este sentido, podemos interpretar que su perspectiva es descolonizadora en la medida que subvierte la relación de subalternidad y dependencia frente a España y Europa, al situar en un mismo nivel a la producción intelectual americana desde su sitial de independencia política y cultural. En consecuencia, Darío, por lo menos discursivamente, completa el proyecto de autonomía cultural propuesto por Andrés Bello medio siglo atrás. De todas formas, observamos que el escritor mantiene a Europa (eso sí, no a España) como norma y criterio de civilización, gesto que puede leerse como la

personales inmediatas y, por tanto, fácilmente neutralizable por otra que ellos consideran de más prioridad. La segunda razón sería precisamente esa otra cuestión prioritaria; es decir, la intervención estadounidense, en cuanto nueva y agresiva manifestación del expansionismo norteamericano" ("La intervención" 195-196). 
búsqueda de legitimarse a través de la aprobación del Viejo Mundo, procurando inscribir la identidad hispanoamericana dentro de la Modernidad. Darío expresa aquí la tensión de los latinoamericanos finiseculares "entre el deseo de sumarse al orden global del modernismo y la ansiedad que provoca la experiencia de la exclusión, por un lado, y la anticipación de futuras exclusiones, por otro" (Siskind 37). No obstante, Darío se esfuerza para que el Modernismo, liderado por él, les pueda entregar a los escritores hispanoamericanos un puesto específico dentro de la literatura mundial, "independiente de la literatura castellana" (329).

\section{Reflexiones finales}

Las crónicas que componen España contemporánea sirvieron como espacios textuales de reflexión ensayística, donde Darío analizó la sociedad, el arte, la literatura, la política y la economía de España. Todo ello, enmarcado dentro de la problemática geohistórica y geopolítica mayor que generó la derrota española del 98 en el campo intelectual y político hispanoamericano, comenzando a percibirse la "urgencia de recrear programas tendientes a conseguir la unidad hispanoamericana, unidad entendida como defensa" (Maíz 123). En esta obra se escenifica también la inestabilidad del lugar de enunciación dariano, ya que es un sujeto que posee una condición de doble pertenencia tanto de una cultura de la resistencia como de la cultura hegemónica occidental. Además, representa las ambigüedades ideológicas propias del Modernismo (Real de Azúa 406), que expresan la compleja y rica red interdiscursiva que se articula en su interior; discursos provenientes de diversas corrientes estético-intelectuales que son de difícil clasificación y que, a veces, pueden parecer contradictorias, pero articulados en el marco de un proyecto hispanoamericanista mayor. Tal proyecto, como revisamos, está elaborado sobre la base de una retórica del desastre que le permite construir a Darío una imagen textual de la España del 98 para sus lectores hispanoamericanos. A partir de esta retórica evalúa la sociedad hispana y la 
relocaliza en relación con Hispanoamérica, situando al subcontinente en una posición de igualdad de condiciones y, en cierta medida, de superioridad frente a la ex Metrópoli, en tanto dentro del proyecto cultural hispanoamericano son los escritores modernistas los llamados a encabezarlo.

Por otra parte, el imperialismo en las crónicas de Darío aparece representado y evaluado como un tipo de sometimiento político y cultural al que él se opone. Sus críticas al imperialismo estadounidense y al viejo imperio español se asocian con una estimación política y cultural del fenómeno, que es una mirada distinta al énfasis economicista que pensadores como John A. Hobson, Vladimir I. Lenin o Rosa Luxemburgo le darán en aquellos años en Europa. El discurso antiimperialista de Darío, en cambio, es de un corte espiritualista y político en relación con el lugar histórico y epistémico de Latinoamérica en el contexto de las luchas inter-imperiales del cambio de siglo. De este modo, el autor de $\mathrm{Azul}$ emerge como un antecedente relevante para comprender el pensamiento antiimperialista en nuestra historia intelectual, ya que demuestra que tal pensamiento, aunque no exento de tensiones, fue un discurso de resistencia propio y de larga data, como en Francisco Bilbao o José Martí y que se proyectará hacia el siglo XX con diferentes modulaciones ideológicas y textuales, dependiendo de las condiciones de producción y enunciación.

Darío se anticipa, en cierto modo, al discurso antiimperialista que eclosionará entre los intelectuales latinoamericanos después del triunfo de la Revolución Rusa y de la fundación de la III Internacional; un pensamiento que nació antes de que el concepto imperialismo fuera adoptado y criticado por los pensadores europeos y estadounidenses como Lenin o Twain. E incluso, en el caso de Darío, su antiimperialismo y protesta contra los Estados Unidos se expresa a través del discurso literario, por ejemplo, en "D. Q" y en su "Oda a Roosevelt".

En definitiva, Darío en sus crónicas manifiesta entonces una perspectiva antiimperialista y descolonizadora que intenta liberarse de la subordinación y dependencia política e intelectual de la que ha sido objeto América y sus habitantes, a través de la revalorización de la cultura hispanoamericana en clave cosmopolita. 
Para ello, se ha apropiado del modelo civilizador y modernizador occidental para adaptarlo creativamente a la realidad geocultural hispanoamericana y, de este modo, revertir la situación de relegación y marginación cultural y política con respecto a Occidente.

\section{Bibliografia}

\section{Fuentes primarias}

Darío, Rubén. "Bronce al soldado Juan". (1891). Rubén Darío. Escritos políticos. Jorge Eduardo Arellano y Pablo Kraudy, editores. Managua: Banco Central de Nicaragua, 2010. 207-210.

. "La insurrección en Cuba". (1895). Escritos dispersos. II. Luis Barcia, editor. La Plata: Universidad Nacional de La Plata, 1977. 13-19.

. "Palabras liminares". Prosas profanas y otros poemas. 1896. Madrid: Editorial Mundo Latino, 1917. 7-11.

. "El triunfo de Calibán" (1898). Carlos Jáuregui, editor. Revista Iberoamericana 184-185 (1998): 451-455. . España contemporánea. 1901. Noel Rivas Bravo, editor. Sevilla: Renacimiento, 2013.

. "Reflexiones de año nuevo parisiense". (1901). Viajes de un cosmopolita extremo. Graciela Montaldo, editora. Buenos Aires: Fondo de Cultura Económica, 2013. 113-119.

. "Andrianamanitra mby an-trano". La caravana pasa. Libro primero. 1902. Günter Schmigalle, editor. Berlín: Tranvía, 2000. 79-98. . "En Londres". La caravana pasa. Libro segundo. 1902. Günter

Schmigalle, editor. Berlín: Academia Nicaragüense de la Lengua/Tranvía, 2005. 27-46. 
CATEDRAL Tomada: Revista literaria latinoamericana / Journal of Latin American Literary Criticism Marcelo Sanhueza

. "Cake-walk". (1903). Viajes de un cosmopolita extremo. Graciela Montaldo, editora. Buenos Aires: Fondo de Cultura Económica, 2013. 349-352.

. Azul... / Cantos de vida y esperanza. Los cisnes y otros poemas.

"Cantos de vida y esperanza. Los cisnes y otros poemas". José María

Martínez, editor. Madrid: Ediciones Cátedra, 2010. 329-466.

. "La raza de Cham". Parisiana. Madrid: Librería de Fernando Fé, 1907. 261-269.

. "Letras chilenas. Francisco Contreras: un libro sobre Italia". Todo al vuelo. Madrid: Renacimiento, 1912. 108-116.

. La vida de Rubén Dario escrita por él mismo. 1912. Barcelona: Casa Editorial Maucci, 1915.

. "Historia de mis libros". (1916). Obras Completas. Volumen XVII.

Madrid: Editorial Mundo Latino, 1919. 57-215.

. "El periodista y su mérito literario". Impresiones y sensaciones. Obras

Completas. Volumen XII. Madrid: Librería Fernando Fé, 1925. 219-220.

. Tantos vigores dispersos: ideas sociales y políticas. Jorge Eduardo Arellano, editor. Managua: Consejo Nacional de la Cultura, 1984.

\section{Fuentes secundarias}

Acereda, Alberto. "La hispanidad amenazada. Rubén Darío y la guerra del 98". BilingualReview/La Revista Bilingüe 25 (2000): 99-110. . "El acecho antidariano. Ataques y deformaciones en torno a Rubén Darío”. Crítica Hispánica 27 (2005): 249-270.

. "Silencios críticos en torno al compromiso ideológico y sociopolítico de Rubén Darío". Cuadernos del CILHA 10 (2009): 150-175.

. "Las otras miradas de Rubén Darío a Estados Unidos". Rubén Darío en su laberinto. Rocío Oviedo, editora. Madrid: Editorial Verbum: 2013. 153-166. 
CATEDRAL Tomada: Revista de crítica literaria latinoamericana / Journal of Latin American Literary Criticism Entre imperios: antiimperialismo e hispanoamericanismo en España contemporánea de Rubén Darío

Allen, David. "Rubén Darío frente a la creciente influencia de los Estados Unidos". Revista Iberoamericana 33 (1967): 387-393.

Altamirano, Carlos. "Introducción general”. Historia de los intelectuales en América Latina. I. La ciudad letrada, de la conquista al modernismo. Jorge Myers, editor. Buenos Aires: Katz Editores, 2009. 9-27.

Arellano, Jorge Eduardo. "Rubén Darío antiimperialista". Casa de las Américas 133 (1982): 104-108.

Barisone, José Alberto. “La perspectiva americanista de Rubén Darío”. Revista del CELEHIS 33 (2017): 11-26.

Bender, Thomas. Historia de los Estados Unidos. Una nación entre naciones. 2006. Alcira Bixio, traductora. Buenos Aires: Siglo XXI, Editores, 2015. Benjamin, Walter. "La obra de arte en la época de su reproductibilidad técnica". (1936). Estética y política. Tomás Joaquín Bartoletti y Julián Fava, traductores. Buenos Aires: Las Cuarenta. 2009. 81-107.

Bonfiglio, Florencia. "Religaciones hispano-americanas en torno del 98: los usos de La Tempestad en el Modernismo (Darío y Rodó)”. Olivar 14 (2010): $71-91$.

Caldera, Norman. Rubén Darío diplomático. Managua: Colección Presidencial Enrique Bolaños, 2006.

Colombi, Beatriz. "Retóricas del viaje a España". Viaje intelectual: migraciones y desplazamientos en América Latina (1880-1915). Rosario: Beatriz Viterbo, 2004. 105-134.

Delgado, Leonel. "Modernidad, tradición y barbarie en la crónica modernista: las estrategias fundacionales de Darío en España contemporánea". Rubén Darío: cosmopolita arraigado. Jeff Browitt y Werner Mackenbach, editores. Managua: Instituto de Historia de Nicaragua y Centroamérica, 2010. 17-40.

Díaz Quiñones, Arcadio. "Hispanismo y Guerra”. Sobre los principios: intelectuales caribeños y la tradición. Buenos Aires: Universidad Nacional de Quilmes, 2006. 65-166. 
Doyle, Michael. "Imperialism and Empire”. Empires. New York: Cornell University Press, 1986. 19-47.

Fernández Retamar, Roberto. “Algunos usos de civilización y barbarie”. Revista Casa de las Américas 102 (1977): 29-52.

González, Aníbal. La crónica modernista hispanoamericana. Madrid: Porrúa, 1983.

Gutiérrez Girardot, Rafael. "Rubén Darío y Madrid”. Anales de literatura hispanoamericana 22 (1993): 151-164.

Hobsbawm, Eric. La era del imperio. 1875-1914. 1987. Juan Faci Lacasta, traductor. Buenos Aires: Crítica, 2012.

Hobson, John A. "Estudio del imperialismo". (1902). Imperialismo. Jesús Fomperosa Aparicio, traductor. Madrid: Capitán Swing Libros, 2009. 13395.

Jáuregui, Carlos. "Los monstruos del latinoamericanismo arielista: variaciones del apetito en la periferia (neo) colonial". Canibalia. Canibalismo, calibanismo, antropofagia cultural y consumo en América Latina. Madrid: Iberoamericana/Vervuert, 2008. 311-391.

Kozel, Andrés, Florencia Grossi y Delfina Moroni. "Introducción”. El imaginario antiimperialista en América Latina. Andrés Kozel y otros, editores. Buenos Aires: CCC/CLACSO, 2015. 7-21.

Kraudy, Pablo. "El pensamiento social y político de Rubén Darío". Rubén Darío. Escritos políticos. Jorge Eduardo Arellano y Pablo Kraudy, editores. Managua: Banco Central de Nicaragua, 2010. 39-96.

Maíz, Claudio. De París a Salamanca. Trayectorias de la Modernidad en Hispanoamérica. Aportes para el estudio del novecentismo. Salamanca: Ediciones Universidad de Salamanca, 2004.

Martínez, José María. “La intervención de Estados Unidos en la guerra de Cuba: la lectura panlatinista de Rubén Darío”. Los últimos días del comienzo. Ensayos sobre la Guerra Hispano-Cubana-Estadounidense. Benigno 
CATEDRAL Tomada: Revista de crítica literaria latinoamericana / Journal of Latin American Literary Criticism Entre imperios: antiimperialismo e hispanoamericanismo en España contemporánea de Rubén Darío

Aguirre y Eduardo Espina, editores. Santiago de Chile: RIL, 2000. 193206.

. "Modernismo literario y modernismo religioso: encuentros y desencuentros en Rubén Darío”. Cuadernos del CILHA 10 (2009): 110175.

. "Introducción”. Azul... / Cantos de vida y esperanza. Los cisnes y otros poemas. 1905. José María Martínez, editor. Madrid: Ediciones Cátedra, 2010. 11-98.

Mignolo, Walter. Historias locales/diseños globales. Colonialidad, conocimientos subalternos y pensamiento fronterizo. 2000. Juanmari Madariaga y Cristina Vega Solis, traductores. Madrid: Ediciones AKAL, 2003.

Montaldo, Graciela. "La cultura invisible: los hispanoamericanos y el problema de América Latina". Ficciones culturales y fábulas de identidad en América Latina. Buenos Aires: Beatriz Viterbo, 2004. 81-139.

Moro, Diana. “La figura revolucionaria de Rubén Darío: un acto performativo de Casa de las Américas”. Anclajes 19 (2016): 40-52.

Muslip, Eduardo. "La autobiografía dariana: un análisis de La vida de Rubén Darío escrita por él mismo”. Crítica Hispánica 27 (2005): 33-48.

Myers, Jorge. "Los intelectuales latinoamericanos desde la colonia hasta el inicio del siglo XX". Historia de los intelectuales en América Latina. I. La ciudad letrada, de la conquista al modernismo. Jorge Myers, editor. Buenos Aires: Katz Editores, 2009. 29-50.

Núñez, César. "Un porvenir cargado de pasado: la España eterna de Rubén Darío”. La protesta de los Cisnes. Coloquio sobre Cantos de vida y esperanza de Rubén Darío. 1905-2005. Enrique Foffani, compilador. Buenos Aires: Ediciones Katatay, 2007. 133-152.

Ortega, Julio. "Formación nacional, cultura y discurso literario en el siglo XIX hispanoamericano". Nuevo Texto Crítico 14-15 (1995): 129-146.

Osterhammel, Jürgen. Colonialism. A Theoretical Overview. Shelley Frisch, traductora. U.S.A: Markus Wiener Publishers, 1997. 
Oviedo, Rocío. "El difícil camino de la paz: pensamiento político de Rubén Darío". Zama/Extraordinario: Rubén Dario (2016): 217-226.

Pita, Alexandra y Carlos Marichal. "Introducción: Pensar el antiimperialismo". Pensar el antiimperialismo. Ensayos de historia intelectual latinoamericana, 1900-1930. Alexandra Pita y Carlos Marichal, compiladores. México. D.F.: El Colegio de México/Universidad de Colima, 2012. 7-36.

Quesada Monge, Rodrigo. “1898: Mark Twain, Cuba, Filipinas y el antiimperialismo en Estados Unidos”. 1898 ¿desastre o reconciliación? Leopoldo Zea y Mario Magallón, compiladores. México. D.F.: Instituto Panamericano de Geografía e Historia/Fondo de Cultura Económica, 2000. 161-178.

Rama, Ángel. Rubén Darío y el modernismo. Caracas: Ediciones de la Biblioteca de la Universidad Central de Venezuela, 1970.

. "Sueños, espíritus, ideología y arte del diálogo modernista con Europa".

El mundo de los sueños. Ángel Rama, editor. Barcelona: Editorial Universitaria de la Universidad de Puerto Rico, 1973. 5-61.

Ramos, Julio. Desencuentros de la modernidad en América Latina. Literatura y Política en el siglo XIX. 1989. Santiago de Chile: Editorial Cuarto Propio, 2003.

Real de Azúa, Carlos. "Modernismos e ideologías". Lectura crítica de la literatura americana. La formación de las culturas nacionales. Saúl Sosnowski, compilador. Caracas: Ayacucho, 1996. 406-436.

Rivas Bravo, Noel. "Estudio preliminar”. España contemporánea. 1901. Noel Rivas Bravo, editor. Sevilla: Renacimiento, 2013.9-67.

Rotker, Susana. La invención de la crónica. 1992. México. D.F.: Fondo de Cultura Económica, 2005.

Schmigalle, Günter. "Más apreciaciones sobre la imagen de España en Rubén Darío". Anales de Literatura Hispanoamericana 32 (2003): 153-163. 
CATEDRAL Tomada: Revista de crítica literaria latinoamericana / Journal of Latin American Literary Criticism Entre imperios: antiimperialismo e hispanoamericanismo en España contemporánea de Rubén Darío

Siskind, Mariano. Deseos cosmopolitas. Modernidad global y literatura mundial en América Latina. 2014. Lilia Mosconi, traductora. Buenos Aires: Fondo de Cultura Económica, 2016.

Spurr, David. La retórica del imperio. El discurso colonial en periodismo, escritura de viajes y administración imperial. 1993. Trad. Cristina Márquez. Santiago de Chile: Ediciones Universidad Alberto Hurtado, 2013.

Tieffemberg, Silvia. "Lugares de enunciación inestables". Telar 11-12 (20132014): 269-283.

Torre, Antonio De la. "Consideraciones sobre la actitud político-social de Rubén Darío”. Revista Iberoamericana 19 (1954): 261-272.

Vilanova, Antonio. “Prólogo". España contemporánea. 1901. Barcelona: Editorial Lumen, 1987. 9-26.

Zanetti, Susana. "Modernidad y religación: una perspectiva continental (18801916)”. América Latina: Palavra, Literatura e Cultura. Vol. II. Ana Pizarro, compiladora. São Paolo: UNICAMP, 1994. 489-534. . "El modernismo y el intelectual como artista: Rubén Darío". Historia de los intelectuales en América Latina. I. La ciudad letrada, de la conquista al modernismo. Jorge Myers, editor. Buenos Aires: Katz Editores, 2008. 523-543.

Zavala, Iris. "The Dialogical Cultural Signs". Colonialism and Culture. Hispanic Modernism and the Social Imaginary. U.S.A: Indiana University Press, 1992. 92-107.

Zea, Leopoldo. “1898, Latinoamérica y la reconciliación iberoamericana”. 1898 ¿desastre o reconciliación? Leopoldo Zea y Mario Magallón, editores. México. D.F.: Instituto Panamericano de Geografía e Historia/Fondo de Cultura Económica, 2000. 7-19.

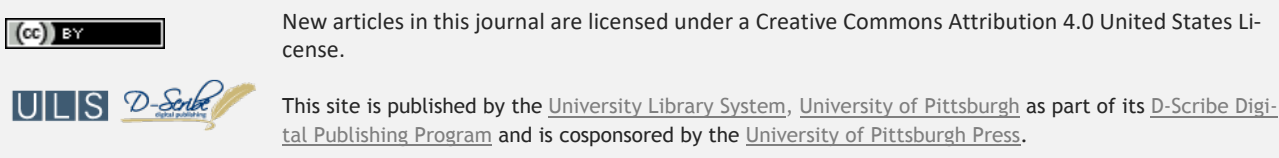
tal Publishing Program and is cosponsored by the University of Pittsburgh Press. 